\author{
УДК 536.24
}

В.П. Желєзний, А.В. Мельник

Одеська національна академія харчових технологій, вул. Дворянська, 1/3, Одеса, 65082

\title{
ЛОКАЛЬНИЙ КОЕФІЦІЄНТ ТЕПЛОВІДДАЧІ ПРИ КИПІННІ РОЗЧИНУ ІЗОБУТАН/ МІНЕРАЛЬНЕ МАСТИЛО В ТРУБІ
}

\begin{abstract}
В статті приведені експериментальні данні по кипенню в трубі разчину холодоагента R600а з мінеральним нафтеновим мастилом ISO VG 15 в гладкій трубі малого діаметру (5.4 мм). Дослідження проводились при тиску кипіння в діапазоні від 62.3 кПа до 82.2 кПа, тепловому потоиі 2754 - $4105 \mathrm{Bm} / \mathrm{M}^{2}$, масовій швидкості 11.90 - $18.54 \kappa 2 /\left(\mathrm{M}^{2} \mathrm{c}\right)$ і концентрації мастила на вході в випарник $0.25-0.5 \%$. В даній статті приведені результати дослідження локального коефіцієнту тепловіддачі при кипінні розчинів холодоагент/мастило в трубі. Показано, щуо суттєве зменшення коефіцієнта тепловіддачі спостерігалось при високих концентрачіях мастила. Коєфіцієнт тепловіддачі при кипінні розчину холодоагент/мастило (РХМ) в нижній частині труби зменшується зі збільшенням масової швидкості.

Ключові слова: Коефічієнт тепловіддачі - Реальне рабоче тіло - Кипіння - Ізобутан

- Розчин холодоагент/мастило - Кониентрачія.
\end{abstract}

\section{В.П. Железный, А.В. Мельник}

Одесская национальная академия пищевых технологий, ул. Дворянская, 1/3, Одесса, 65082

\section{ЛОКАЛЬНЫЙ КОЭФФИЦИЕНТ ТЕПЛООТДАЧИ ПРИ КИПЕНИИ РАСТВОРА ИЗОБУТАН/МИНЕРАЛЬНОЕ МАСЛО В ТРУБЕ}

\begin{abstract}
В статье приведены экспериментальные данные о кипении в трубе раствора хладагента R600а с минеральным нафтеновым маслом ISO VG 15 в гладкой трубе малого диаметра (5.4 мм). Исследования проводились при давлении кипения в диапазоне от 62.3 кПа до 82.2 кПа, тепловом потоке 2754 - $4105 \mathrm{Bm} / \mathrm{M}^{2}$, массовой скорости 11.90 - 18.54 кг/ $\left(\mathrm{M}^{2} c\right)$ и концентрации масла на входе в испаритель 0.25 - 0.5\%. В данной статье приведень результаты исследования локального коэффициента теплоотдачи при кипении растворов хладагент/ масло в трубе. Показано, что существенное уменьшение коэффициента теплоотдачи наблюдалось при высоких концентрациях масла. Коэффициент теплоотдачи при кипении раствора хладагент/масло (РХМ) в нижней части трубы уменьшается с увеличением массовой скорости.

Ключевые слова: Коэффициент теплоотдачи - Реальное рабочее тело - Кипение Изобутан - Раствор хладагент/масла - Концентрация.
\end{abstract}

\section{INTRODUCTION}

During operation of vapor compression refrigeration machine the certain amount of compressor oil always circulates with the refrigerant through the cycle of a compressor system. Lack of oil separators in a small refrigeration systems leads to an unavoidable circulation of small amount of oil through refrigeration system that together with refrigerant form refrigerant/oil solution (ROS). Mutual solubility of the compressor oil with the refrigerant has significant impact both on heat transfer in the apparatus as well as on the refrigeration machine operation in general. For this reason, it is necessary to have information about the influence of the compressor oil admixtures in the refrigerant on the boiling processes of the real working fluid (RWF) in an evaporator.
According to the data $[1,2,3,4]$, presence of insignificant oil impurities in the refrigerant have a significant impact on heat transfer intensity and fluid flow boiling modes in the evaporator.

The oil presence in RWF at high concentrations (about 5\%) decreases the flow boiling in the pipe, mainly due to its high mixture viscosity. On the other hand, a great number of researchers [e.g., 2, 5, 6], have observed that some lubricants enhanced the flow boiling at oil concentration in the refrigerant below $3 \%$. The enhancement of the boiling processes in the pipe depends on the vapor quality, oil species, pipe types, and heat fluxes. From the foregoing, the account of the influence of oil impurities in the refrigerant under the flow boiling in the pipe is the complex problem of thermophysics which requires further investigation. 


\section{EXPERIMENTAL SETUP}

In order to study the influence of oil impurities on the characteristics of isobutane boiling process in the evaporator complex experimental setup has been designed. The schematic diagram of test apparatus is illustrated in figure 1 .

The refrigerant vapors together with small oil droplets, which are formed in the process working fluid of compression by compressor 1 model CKN 150 (nominal cooling capacity $167 \mathrm{~W}$ ), are injected into condenser 2. After the working fluids vapors condensation, the liquid solution of the refrigerant with oil impurities (ROS) enters the calorimetric flow meter 4, where further subcooling takes place. Filter-drier 5 model ADK-052S, sight glass 6 and throttling device 7 are installed at the exit of flow meter. Then, the working fluid flows into the test section (evaporator), where the most of refrigerant is evaporated, and su- perheated vapor with the last of ROS goes to the input of the compressor. Heat loads in the evaporator were ensured through Joule heat by passing a direct current through a thin-walled stainless steel tube. For this purpose was used a DC power supply model BVP $30 \mathrm{~V} / 50 \mathrm{~A}$ with an uncertainty $\pm 0.1 \mathrm{~A}, \pm 0.1 \mathrm{~V}$. Evaporator 8 is located in vacuum camera 9 , that allows to conduct the study of the RWF flow boiling under adiabatic conditions. The aluminum foil wrapped around the evaporator excludes the heat loss by radiation from the walls of vacuum camera.

As a throttling device the expansion valve 7 was used that provided the possibility of discrete changing of small amount of the working fluid. To ensure the adiabatic conditions of throttling, expansion valve 7 was located inside the vacuum camera. The apparatus was provided with remote control of throttle device by means of electric motor with gear.

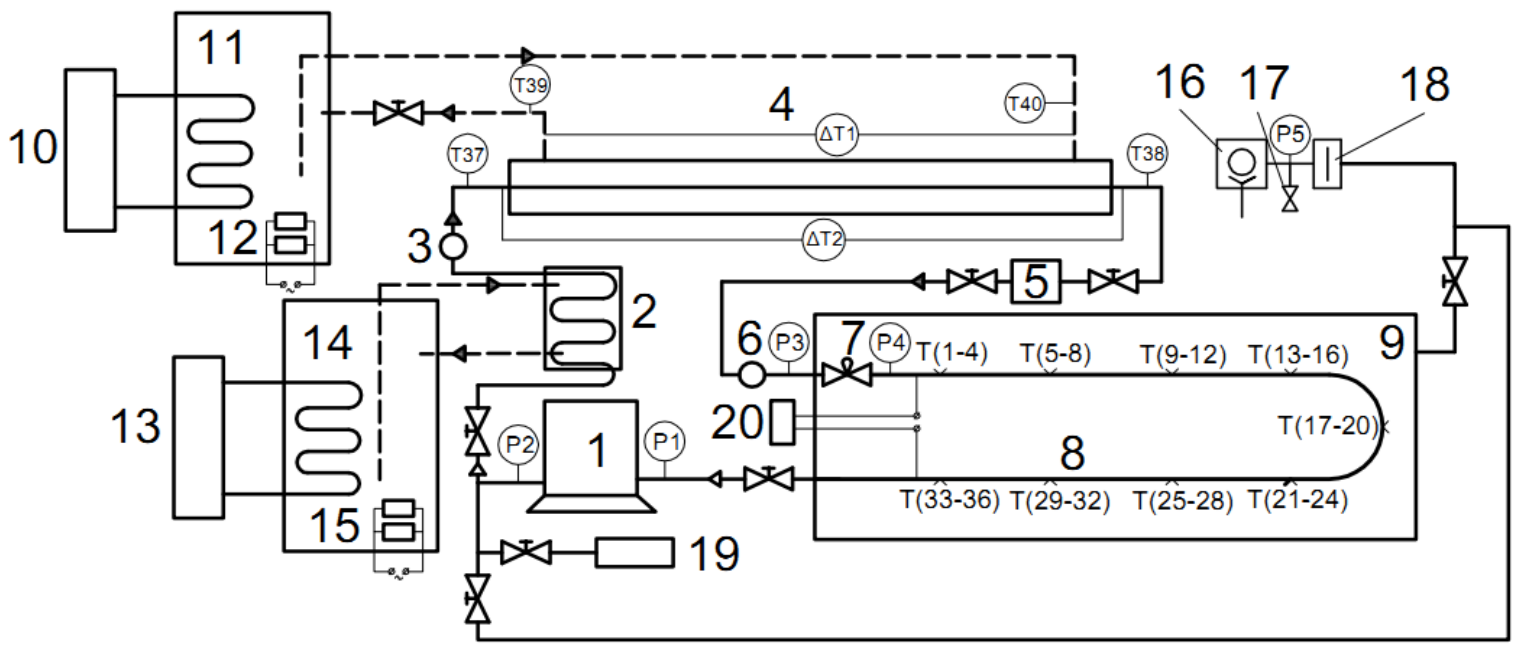

Figure 1 - Schematic diagram of the experimental setup for the study of heat transfer at boiling of $R W F$ in a pipe.

1 - compressor; 2 - condenser; 3,6 - sight glass; 4 - calorimetric flow meter; 5 -filter-drier; 7 - throttling device; 8 -test section - thin-walled stainless steel tube (evaporator); 9 -vacuum camera; 10,13 - cooling system; 11,14 - thermostat; 12,15 - heater; 16 -vacuum pump; 17 -valve; 18 -vacuum trap; 19 - charging balloon; $20-D C$ power supply.

The experimental setup is equipped with three pressure gauges (with accuracy class 0.5), which measured the pressure at the inlet of the working fluid to the evaporator P4, at the inlet of the working fluid to the throttle device P3 and in the vacuum camera P5.

The test section of experimental setup was designed as smooth stainless steel U-tube with inner diameter $d_{\text {inner }}=5.4 \mathrm{~mm} \pm 0.05 \mathrm{~mm}$, wall thickness $\delta=0.3$ $m m \pm 0.05 \mathrm{~mm}$ and roughness 0.5-0.8 $\mu \mathrm{m}$. The length of the test section was $L=1691 \mathrm{~mm} \pm 2 \mathrm{~mm}$. The evaporator is divided into nine sections. On the bounds of each section copper-constantan type-T thermocouples for measuring liquid RWF boiling temperatures and evaporator wall temperature are installed. The evaporator sections are linked by short rubber hoses (distance between sections of the evaporator is not greater than $5 \mathrm{~mm}$ ), in which the thermocouples are inserted.
The thermocouples for measuring the average over the section of pipe wall temperature are wound on the tube (a few turns to improve the thermal contact). On each evaporator section the differential thermocouples are located which are required to measure the temperature difference between the evaporator wall and the boiling working fluid in the upper and lower points of the evaporator.

Voltages of the nine thermocouples are measured simultaneously by a multimeter model TE 5065 with an error $\pm 0.0035 \mathrm{mV}$.

One of the most important parameters of the boiling process in the pipe, which is necessary for the interpretation of the experimental data, is the mass flow rate of RWF on the test section. To determine the amount of working fluid the calorimetric flow meter 4 was used. The differential temperatures between inlet 
and outlet of water and the working fluid are measured by the differential thermocouples type-T.

The mass flow rate of ROS was determined by the approximation equation

$$
\dot{M}_{R O S}=\dot{M}_{W}\left(1.6086 \cdot \Delta T_{W} / \Delta T_{R O S}-0.1331\right)
$$

where, $\dot{M}_{W}$ - mass flow rate of water through the calorimetric flow meter, $\mathrm{kg} / \mathrm{c}, \Delta T_{W}$ - differential temperature between inlet and outlet of water, $K ; \Delta T_{R O S}-$ differential temperature between inlet and outlet of working fluid, $K$.

The nominal oil concentration in the compressor system is defined as the mass fraction of oil in the supercooled region of the refrigerant liquid phase before the throttling device. When using reciprocating compressors the working fluid comprises oil from $0.5 \%$ to $1 \%$ by weight. For domestic refrigeration equipment, which uses reciprocating compressors, oil concentration before throttling device does not exceed $2-3 \%$ as usually [7]. In order to determine the oil concentration before the throttling device, a series of experiments with sampling ROS by liquid phase before the throttling device was conducted. The sampling procedure occurred in the following sequence: achievement of permanence in time of mode parameters and recording all the necessary values, intake of the small amount of ROS by syringe through the rubber hose placed on the discharge line before the throttle device. The intake was carried out in a pre-weighed and evacuated balloon. Then the balloon was weighed, and the weight of ROS in the sample is measured. After the prolonged (1.5 hours) heating at a temperature of about $75^{\circ} \mathrm{C}$ and vacuum treatment, the entire refrigerant is removed from the balloon and the mass of oil in the sample is determined by weighing.

Dependence of oil concentration before throttling device versus mass flow rate of RWF is shown in figure 2 .

The obtained experimental data of oil concentration before throttling device were approximated by the equation

$$
\begin{aligned}
& w_{n o}=-9.5-70393.2 \cdot \dot{M}_{R O S}-11268.6 \times \\
& \times \dot{M}_{R O S} \cdot \ln \left(\dot{M}_{R O S}\right)+0.00106 / \dot{M}_{R O S}
\end{aligned}
$$

where, $\dot{M}_{R O S}$ - mass flow rate of ROS, $\mathrm{kg} / \mathrm{s}$.

\section{DATA PROCESSING}

The present study of local values of the heat transfer coefficient during boiling of RWF in the pipe has a number of features compared with previously published data in the literature [e.g., 1, 3, 4, 8, 9]. The experimental data on the thermal properties of the solutions R600a/ISO VG 15 were used to processing the data instead calculated [10].

The specific heat flux is defined by equation

$$
q=\mathrm{W}_{\text {test }} /\left(\pi \cdot d_{\text {inner }} \cdot L\right)
$$

where, $W_{\text {test }}-$ heat load on the evaporator, $W$;

$d_{\text {inner }}$ - inner diameter of test section tube (evaporator), $m ; L$ - length of the test section, $m$.

Local flow boiling heat transfer coefficient of RWF in the tube is calculated by the equation

$$
\alpha_{\text {local }}=q /\left(T_{w}-T_{b u b}\right)
$$

where, $T_{w}$ - wall temperature at different sections of the evaporator, $K ; T_{b u b}$-temperature of boiling liquid RWF at different sections of the evaporator, $K$.

Local temperature difference $\left(T_{w}-T_{b u b}\right)$ in this study was defined as the difference between the wall temperature (hot junction thermocouple mounted through electrically insulating material on the surface of the pipe) and the temperature of the RWF boiling at a certain point of tube.

The ROS mass velocity on the test section is calculated by the equation

$$
G=4 \cdot \dot{M}_{R O S} /\left(\pi \cdot d_{\text {inner }}^{2}\right)
$$

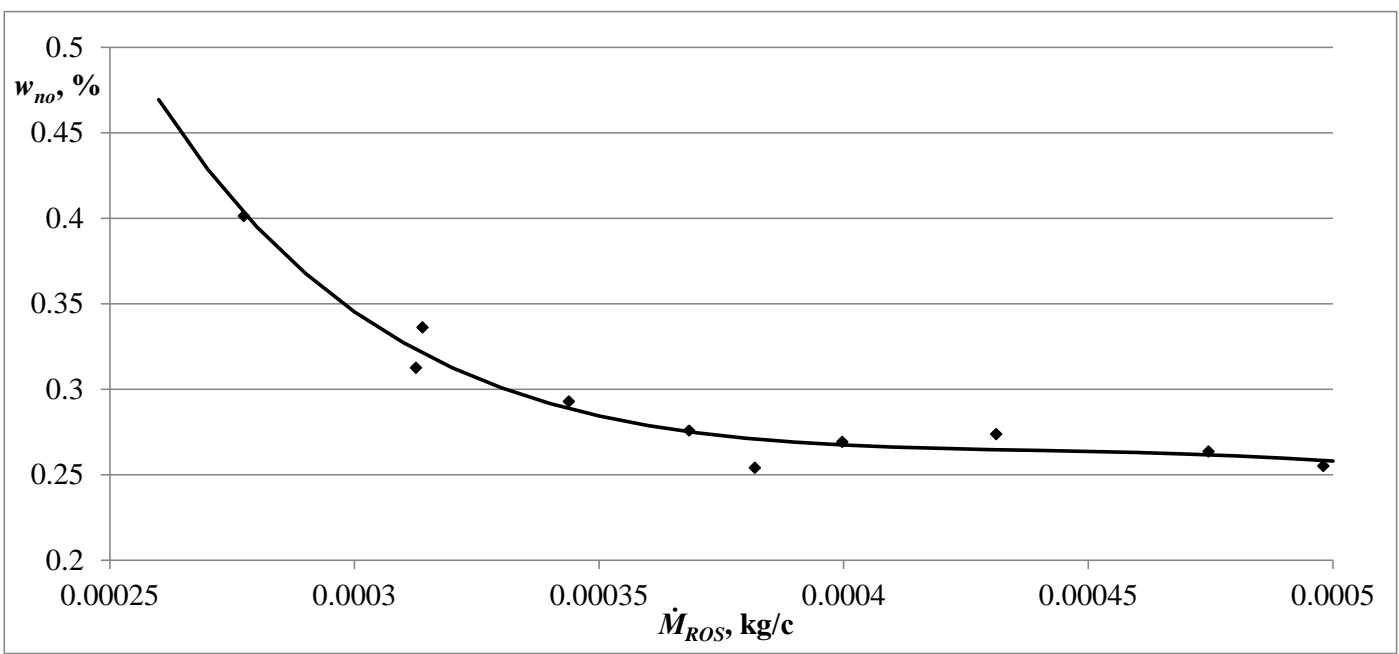

Figure 2 - Dependence of oil concentration before throttling device versus mass flow rate of RWF 
To determine the local vapor qualities RWF in the evaporator $x^{R O S}$ local it is necessary to have information about the enthalpy before throttling device $h^{R O S}$ in. The enthalpy value is determined using experimental data on thermophysical properties of solution R600a/ISO VG 15 and calculated by the equation [10]

$$
\ln \left(h_{i n}^{R O S}\right)=\ln \left(h_{c}^{R O S}\right)+h_{0}{ }^{\prime} \cdot \tau^{\beta \cdot F_{h}{ }^{\prime}(\tau)}
$$

where $h_{0}, \beta-$ coefficients, defined from the experimental data [10]; $h_{c}$ - enthalpy value at critical point, $k J / k g ; \tau=\ln \left(T_{c} / T\right)$ - reduced temperature; $F h^{\prime}(\tau)$ - universal crossover function for the non-associated substances [10]

Local enthalpies of RWF on the evaporator sections are calculated by the equation

$$
h_{\text {local }}^{R O S}=h_{\text {in }}^{R O S}+W_{\text {test }} \cdot s /\left(L \cdot \dot{M}_{r, o}\right)
$$

where, $s-$ the distance from the beginning of the evaporator to the measurement site, $m$.

The enthalpy of oil ISO VG $15 h_{\text {local }}{ }^{O}$ was taken from the experimental data [10]. Information for the enthalpy of the R600a in liquid $h_{\text {local }}{ }^{R, l}$ and vapor $h_{\text {local }}^{R, g}$ phases was taken from the data bases [11].

Local vapor qualities are defined by equation [4]

$$
\begin{aligned}
& x_{\text {local }}^{R O S}=\left(\dot{M}_{R O S} \cdot h_{\text {local }}^{R O S}-\dot{M}_{O} \cdot h_{\text {local }}^{O}-\right. \\
& \left.-\dot{M}_{R} \cdot h_{\text {local }}^{R, l}\right) /\left(\dot{M}_{R O S} \cdot\left(h_{\text {local }}^{R, g}-h_{\text {local }}^{R, l}\right)\right)
\end{aligned}
$$

where, $\dot{M}_{R}$ - mass flow rate of refrigerant, $\mathrm{kg} / \mathrm{s} ; \dot{M}_{O}-$ mass flow rate of oil, $\mathrm{kg} / \mathrm{s}$.

Local oil concentrations in the refrigerant in different sections of the evaporator are defined by equation [4]

$$
w_{\text {local }}=w_{\text {no }} /\left(1-x_{\text {local }}^{\text {ROS }}\right)
$$

\section{RESULTS AND DISCUSSION}

In the studies the solution of isobutane (R600a) with compressor mineral naphthenic oil ISO VG 15 have been used as the working fluid.

At designed by the authors experimental setup were conducted studies of local heat transfer coefficients during working fluid boiling in the evaporator. Specific heat flux $q$ varied from 2754 to $4105 \mathrm{~W} / \mathrm{m}^{2}$. RWF mass velocity $G$ varied between 11.90 to 18.54 $\mathrm{kg} /\left(\mathrm{m}^{2} \cdot \mathrm{s}\right)$. The measuring of the working fluid boiling process parameters was produced only after reaching equilibrium processes in the evaporator: the constant of RWF flow rate, constant in time values of pressure gauges and thermocouples.

The boiling process in the evaporator can be divided into three main areas: I - the area where in the mechanism of heat transfer nucleate boiling dominates, II - the area where in the mechanism of heat transfer convective evaporation dominates, III - area with monotonic deterioration of heat transfer coefficient.

To describe the experimental data in boiling areas I and III the following approximation equations were used

$$
\alpha_{\text {local }}^{I, I I I}=A+B \cdot G+C \cdot q
$$

where $A, B, C$ - coefficients dependencies from the local concentration of oil are fitted by correlations

$$
\begin{gathered}
A=\exp \left(-34.9+285 \cdot w_{\text {local }} \times\right. \\
\times \ln \left(w_{\text {local }}\right)-251.9 / \ln \left(w_{\text {local }}\right) \\
B=-3721+1.96 \cdot 10^{4} \times \\
\times w_{\text {local }}-738.6 \cdot \ln \left(w_{\text {local }}\right) \\
C=6.1+183.8 \cdot w_{\text {local }}^{2} \times \\
\quad \times \ln \left(w_{\text {local }}\right)-0.5 / w_{\text {local }} 0.5
\end{gathered}
$$

Heat transfer coefficient of ROS in boiling area II is defined by approximation equation

$$
\begin{aligned}
& \alpha_{\text {local }}^{I I}=D+E / G+F \cdot q+ \\
& +H / G^{2}+J \cdot q^{2}+K \cdot q / G
\end{aligned}
$$

where $D, E, F, H, J, K$ - coefficients dependencies from the local concentration of oil are fitted by correlations

$$
\begin{aligned}
& D=-4.1 \cdot 10^{5}+2.53 \cdot 10^{10} \times \\
& \times w_{\text {local }}{ }^{3}+2.89 \cdot 10^{3} / w_{\text {local }} \\
& E=6.29 \cdot 10^{6}-4.76 \cdot 10^{11} \cdot w_{\text {local }}{ }^{3}+ \\
& +8.89 \cdot 10^{3} \cdot \ln \left(w_{\text {local }}\right) / w_{\text {local }} \\
& F=227.57-9.46 \cdot 10^{6} \times \\
& \times w_{\text {local }}{ }^{3}-9.05 \cdot\left(\ln \left(w_{\text {local }}\right)\right)^{2} \\
& H=-2.32 \cdot 10^{7}+1.94 \cdot 10^{12} \times \\
& \times w_{\text {local }}{ }^{3}+1.38 \cdot 10^{4} / w_{\text {local }} 1.5 \\
& J=9.96 \cdot 10^{-3}+861 \times \\
& \times w_{\text {local }}{ }^{3}-0.13 \cdot w_{\text {local }} 0.5 \\
& K=-1.71 \cdot 10^{3}+8.51 \cdot 10^{7} \times \\
& \times w_{\text {local }}{ }^{3}+138.65 / w_{\text {local }} 0.5
\end{aligned}
$$


The deviations of calculated values of heat transfer coefficient from the experimental values are presented on the figures 3 and 4 .

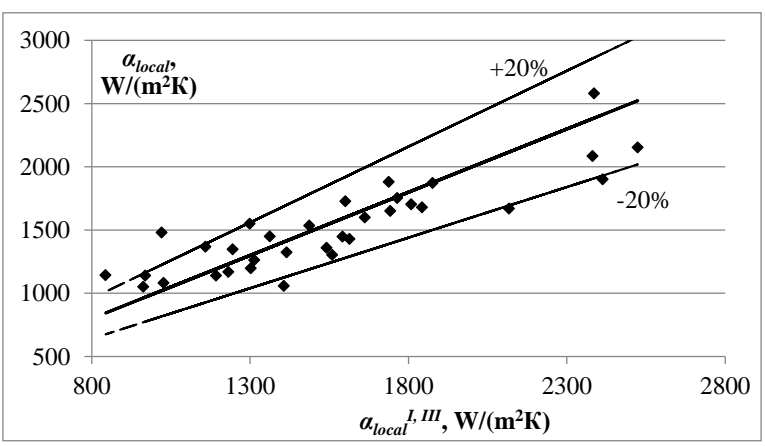

Figure 3 -Diagram of heat transfer coefficient calculated values deviations from the experimental for areas of boiling I and III

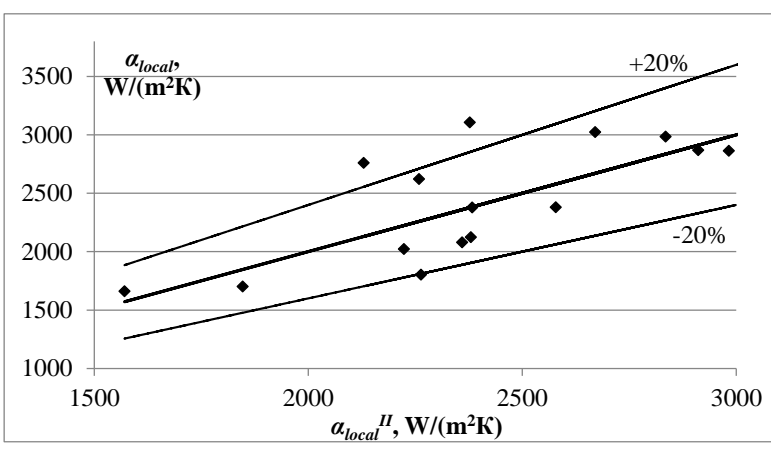

Figure 4 -Diagram of heat transfer coefficient calculated values deviations from the experimental for area of boiling II
The experimental data concerning the heat transfer coefficient at the boiling of the working fluid R600a/ISO VG 15 in the lower part of the tube on the various sections of the evaporator are shown on the figures 5 and 6.

The thermodynamic parameters of the compressor system are listed in the table 1 .

In the process of the executed researches it was revealed that the heat transfer coefficient decreases rapidly at high concentrations of oil. Author [12] pointed out that the oil presence might delay this dryout, which was a positive factor. It should be noted that the formation of oil enriched boundary layer ROS near the inner wall of the evaporator change the laminar flow on the turbulent and significantly decreases heat transfer by convection at high concentrations of oil. In the process of ROS boiling, the oil concentration in the evaporator increases, leading to an increase in ROS viscosity [e.g., 12, 13]. In this case a thin enriched oil boundary layer ROS covers almost all inner surface of the tube. Additional thermal resistance of this layer leads to reducing of the intensity of RWF boiling in the evaporator.

It should be noted, that the boiling heat transfer coefficient RWF decreases with increasing of mass velocity. Authors suggested that this effect can be associated with decrease in nucleate boiling. Author [14] pointed out that oil has a positive effect in a smooth tube at small mass velocities. Furthermore, increasing of mass velocity of RWF leads to shift the maximum of heat transfer coefficient towards lower values of the oil concentrations in time of ROS boiling.

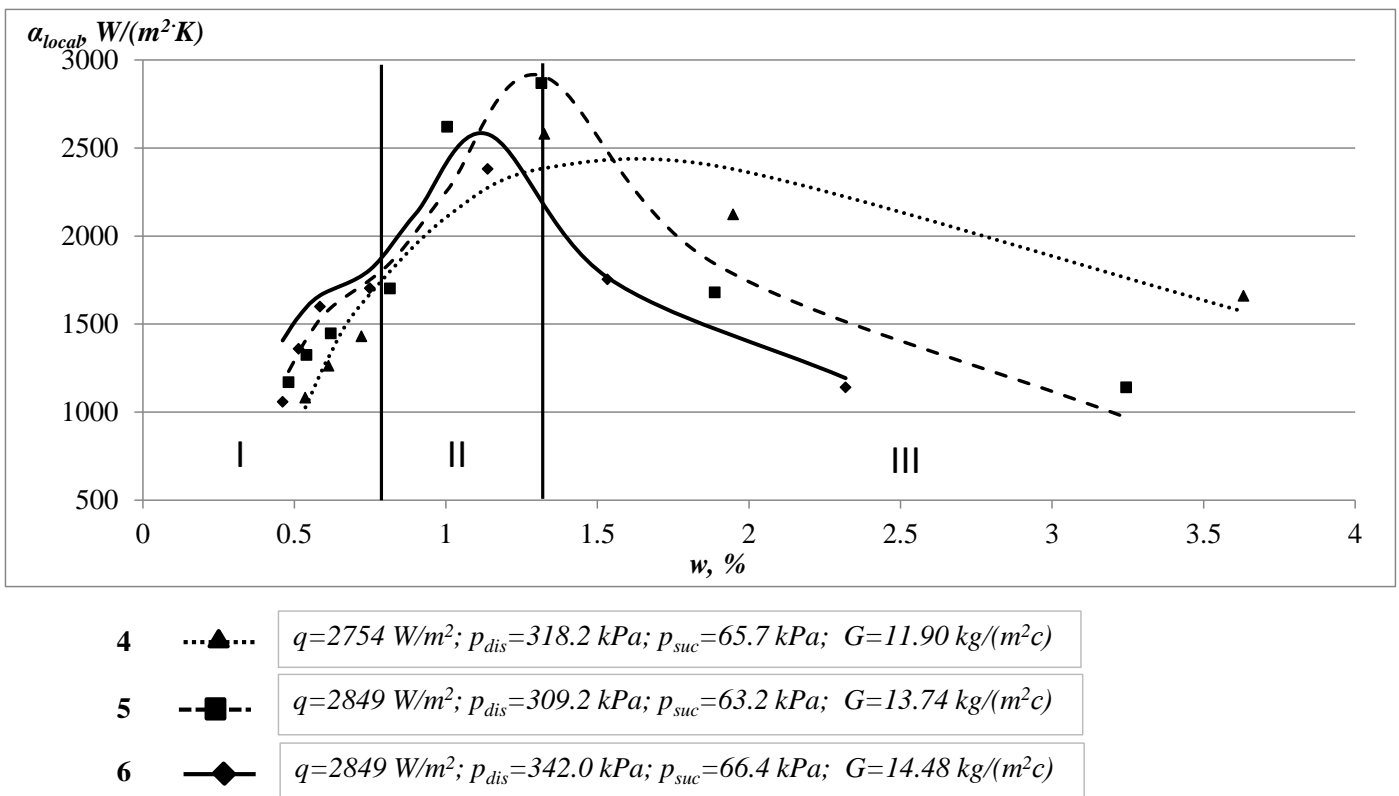

Figure 5 - The dependence of the local heat transfer coefficient from concentration of oil at $G=$ const 
Table 1 - The thermodynamic parameters of the compressor system

\begin{tabular}{ccccccc}
\hline № mode & $\begin{array}{c}p_{\text {suc }} \\
(\mathrm{kPa})\end{array}$ & $\begin{array}{c}p_{\text {dis }} \\
(\mathrm{kPa})\end{array}$ & $\begin{array}{c}q \\
\left(\mathrm{~W} / \mathrm{m}^{2}\right)\end{array}$ & $\begin{array}{c}\dot{M} \cdot 10^{3} \\
(\mathrm{~kg} / \mathrm{c})\end{array}$ & $\begin{array}{c}G \\
\left(\mathrm{~kg} / \mathrm{m}^{2} \mathrm{c}\right)\end{array}$ & $\begin{array}{c}w_{\text {no }} \\
(\%)\end{array}$ \\
\hline 1 & 62.3 & 326.4 & 3836 & 0.422 & 18.46 & 0.27 \\
\hline 2 & 82.2 & 334.9 & 4019 & 0.424 & 18.54 & 0.27 \\
\hline 3 & 76.8 & 345.0 & 4105 & 0.421 & 18.41 & 0.27 \\
\hline 4 & 65.7 & 318.2 & 2754 & 0.272 & 11.90 & 0.33 \\
\hline 5 & 63.2 & 309.2 & 2849 & 0.314 & 13.74 & 0.31 \\
\hline 6 & 66.4 & 342.0 & 2849 & 0.331 & 14.48 & 0.30 \\
\hline
\end{tabular}

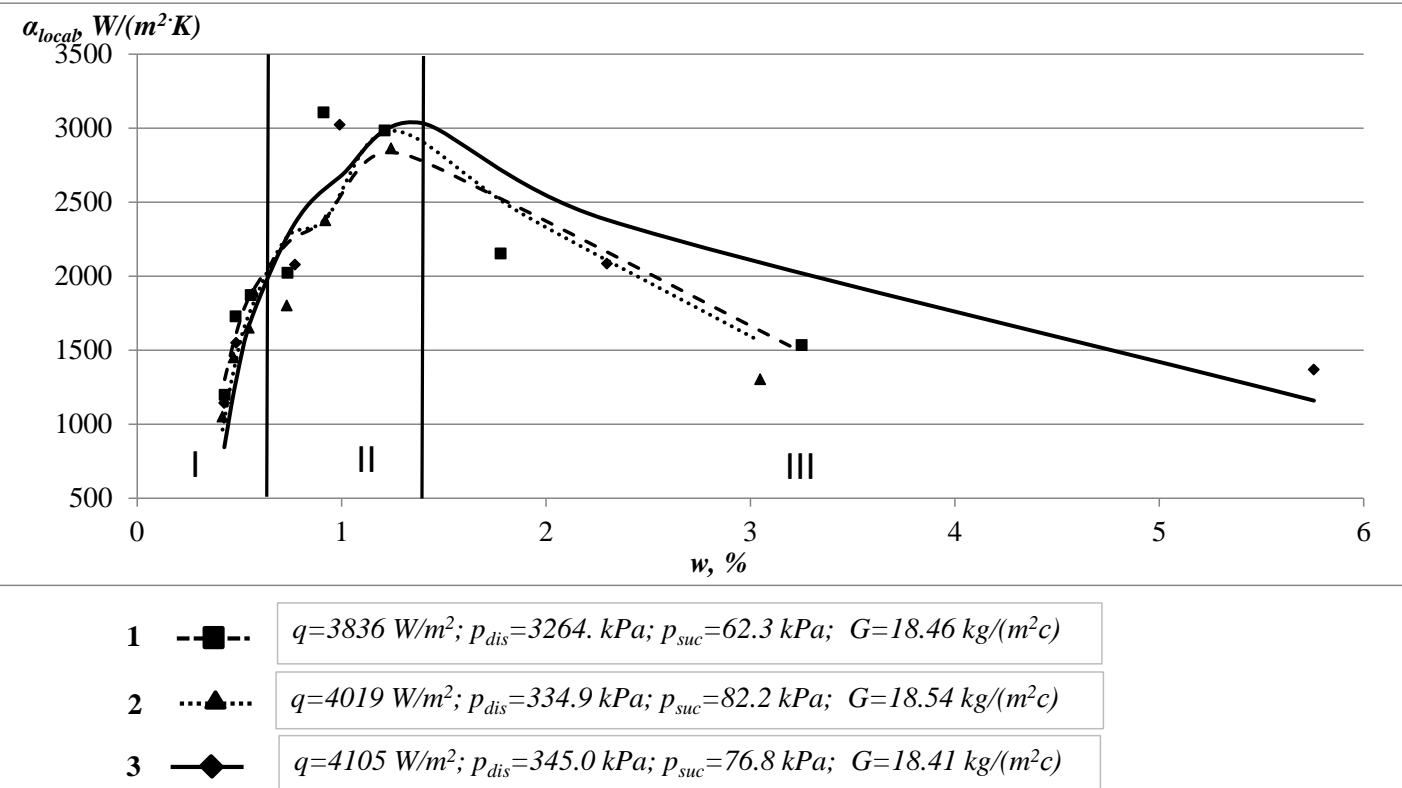

Figure 6 - The dependence of the local heat transfer coefficient from concentration of oil at $q=$ const

However, the intensity of ROS boiling at the bottom of the tube was considerably higher than at the top. It shows that the RWF flow in the evaporator is stratified.

All effects that were considered above have a negative effect of oil impurities in the refrigerant on the processes of RWF boiling in the evaporator.

\section{CONCLUSIONS}

The influence of the compressor oil ISO VG 15 admixtures in the refrigerant on the boiling processes of the real working fluid in the evaporator are experimentally investigated at present study.

The technique of definition of the local heat transfer coefficient depending on the concentration of oil is developed. The approximation equations were shown to predict measured flow boiling heat transfer coefficients for various heat fluxes and mass velocities within $20 \%$.

The experimental results show that impact of the compressor oil admixtures on the processes of the ROS boiling in the evaporator has multiple-factor nature. Heat transfer coefficient at the RWF boiling de- pends on the concentration of oil in the refrigerant, heat flux, foaming process, flow rate and flow regime of the working fluid in the evaporator.

The next stage of experimental data processing is the thermodynamic modeling of boiling ROS in the pipe using experimental data concerning properties of the real working fluid [10].

\section{REFERENCES}

1. Thome J. R. Boiling of new refrigerants: A stateof-the-art review // International Jornal of Refrigeration-Revue Internationale du Froid. - 1996. - v 19. p. $435-457$.

2. Filho E.P., Cheng L., Thome J.R. Flow boiling characteristics and flow pattern visualization of refrigerant/lubricant oil mixtures // International Jornal of Refrigeration. - 2009. - v 32. - p. 185-202.

3. Hu H., Ding G., Huang X. Measurement and correlation of flow-boiling heat transfer of a R410a/oil mixture inside a $4.18 \mathrm{~mm}$ straight smooth tube // HVAC\&R Research. — 2009. — v 15. — p. 287-314. 4. Wei W., Ding G., Hu H. Influence of lubricant oil on heat transfer performance of refrigerant flow boil- 
ing inside small diameter tubes. Part 1: Experimental study. // Experimental Thermal and Fluid Science. 2007. — v 32. - p. 67-76.

5. Eckels, Doerr S., Pate T.M., In-tube heat transfer and pressure drop of R134a and ester lubricant mixtures in a smooth tube and a micro-fin tube: part 1 evaporation. // ASHRAE. — 1994a. — v 100. p. 265-282.

6. Schlager L.M., Pate M.B., Bergles A.E. Performance predictions of refrigerant-oil mixtures in smooth and internally finned tubes, part I: literature review // ASHRAE Trans. — 1990a. — v 96. p. $160-169$.

7. Рабочие тела парокомпрессорных холодильных машин: свойства, анализ, применение: моногр. / В.П. Железный, Ю.В. Семенюк - Одесса: Феникс, 2012. - $420 \mathrm{c}$

Rabochie tela parokompressornih holodilnih mashin: svoistva, analiz, primenenie: monogr. / V.P. Zhelezny, Y.V. Semenyuk - Odessa: Fenics, 2012. - 420 s.

8. Wen M.Y., Ho C.Y., Jang J.K. Boiling heat trandfer of refrigerant R600a/R290-oil mixtures in the serpentine small-diameter U-tubes // Applied Thermal Engineering. — 2007. — v 27. — p. 2353-2362.

9. Shen B., Groll E. Critical literature review of lubricant influence on refrigerant heat transfer and pressure drop. Final report // HVAC\&R Research. 2003. - p. 199.

10.Zhelezny V.P., Nichenko S.V., Semenyuk Yu. V., Skripov P. V. Experimental investigation of the enthalpy of isobutane-compressor oil solutions // J. Chem. Eng. Data. - 2010. — v 55. — p. 1322-1326. 11. McLinden, M. O., Klein, S. A., Lemmon, E. W. and Peskin, A. P. G. 2003, NIST Standard Reference Database 23, NIST Thermodynamic Properties of Refrigerants and Refrigerants Mixtures Database (REFPROP), Version 7.1 (Gaithersburg: National Institute of Standard and Technology).

12. Kattan N., Thome J.R., Favrat D. Flow boiling in horizontal tubes: Part 1 - development of a diabatic two-phase flow pattern map // Journal of heat transferTransactions of the ASME. - 1998a. — v 120. p. $140-147$.

13. Hambraeus K. Heat transfer of oil-comtaminated HFC134a in a horizontal evaporator. // International Jornal of Refrigeration-Revue Internationale du Froid. - 1995. — v 18. - p. 87-99.

14. Cho, Tae K. Condensation heat transfer for R22 and $\mathrm{R} 407 \mathrm{C}$ refrigerant-oil mixtures in a microfin tube with a U-bend // International Journal of Heat and Mass Transfer. - 2001. — v 44. — p. 2043-2051.

\section{V.P. Zhelezny, A.V. Melnik}

Odessa National Academy of Food Technologies, Dvoryanskaya st., 1/3, Odessa, 65082

\section{THE LOCAL HEAT TRANSFER COEFFICIENT AT THE BOILING OF THE ISOBUTANE/ MINERAL OIL SOLUTION FLOW IN THE PIPE}

Experimental data for refrigerant R600a mixed with the compressor mineral naphthenic oil ISO VG 15 boiling in the smooth small-diameter $(5.4 \mathrm{~mm})$ tube are reported. The tests were conducted at the inlet pressure psuc in the range from 62.3 to $82.2 \mathrm{kPa}$, heat flux from 2754 to $4105 \mathrm{~W} / \mathrm{m}^{2}$, mass velocity varied between 11.90 to $18.54 \mathrm{~kg} /\left(\mathrm{m}^{2} \cdot \mathrm{s}\right)$ and oil concentrations at the inlet to the evaporator from 0.25 to $0.5 \%$ by mass. The results of the research of the local heat transfer coefficient at the boiling of the isobutane/compressor oil solution flow are given in the paper. It is shown that the substantial reduction of heat transfer coefficient was observed at high concentrations of oil. In addition, during the boiling of the refrigerant/oil solution the heat transfer coefficient in the lower part of the pipe is decreasing with mass velocity increasing.

Keywords: Heat transfer coefficient - Real work fluid -Boiling - Isobutan - Refrigerant/oil solution Concentration.

Отримана в редакції 04.02.2014, прийнята до друку 04.03.2014 